\begin{tabular}{|c|c|c|}
\hline & Cell Physiol Biochem 2012 & \\
\hline & DOI: 10.1159/000339069 & (C) 2012 S. Karger AG, Basel \\
\hline & $\begin{array}{l}\text { Published online: June 26, } 2012 \\
\text { Accepted: May 24, } 2012\end{array}$ & 1015-8987/12/0302-0347\$38.00/0 \\
\hline
\end{tabular}

\title{
Expression and Function of Monoacylglycerol Lipase in Mouse $\beta$-cells and Human Islets of Langerhans
}

\author{
Chen Li Alonso Vilches-Flores Min Zhao Stephanie A. Amiel Peter M. \\ Jones Shanta J. Persaud
}

Diabetes Research Group, Division of Diabetes \& Nutritional Sciences, King's College London, London

\section{Key Words}

Monoacylglycerol lipase $•$ Cannabinoid $\bullet \beta$-cells $•$ Human Islets $\bullet$ Insulin Secretion

\begin{abstract}
Elements of the endocannabinoid system (ECS) are expressed by islet endocrine cells and activation of $C B 1$ and $C B 2$ cannabinoid receptors regulates insulin secretion from mouse and human $\beta$-cells. The current study aimed to investigate the expression and function, in mouse and human $\beta$-cells, of monoacylglycerol lipase (MGL), an enzyme that facilitates degradation of the endocannabinoid 2-arachidonoylglycerol (2-AG). We found that MGL mRNA is expressed by MIN6 $\beta$-cells, mouse islets, human islets and enriched human islet $\beta$-cells, and immunohistochemistry indicated that MGL localisation in human islets is consistent with its expression by some $\beta$ - and - $\alpha$-cells. Blockade of MGL activity with the pharmacological inhibitor URB602 led to increased $\left[\mathrm{Ca}^{2+}\right]_{i}$ and enhanced insulin secretion from MIN6 $\beta$-cells, and MGL inhibition also elevated insulin and glucagon secretion from isolated human islets in vitro. These data imply a stimulatory role for endogenous $2-A G$ in islets that is amplified when its degradation is blocked.
\end{abstract}

Copyright $\odot 2012$ S. Karger AG, Basel

\section{Introduction}

The $\beta$-cell signal transduction cascades responsible for regulated secretion of insulin have been investigated in detail, and several key signalling pathways have been identified. 


\section{Cellular Physiology Cell Physiol Biochem 2012;30:347-358 \begin{tabular}{ll|l} 
and Biochemistry & $\begin{array}{l}\text { DOI: 10.1159/000339069 } \\
\text { Published online: June 26, 2012 }\end{array}$ & $\begin{array}{l}\text { } 2012 \text { S. Karger AG, Basel } \\
\text { www.karger.com/cpb }\end{array}$ \\
\cline { 2 - 3 } & Li/Vilches-Flores/Zhao/Amiel/Jones/Persaud: Inhibition of Monoacylglycerol Lipase
\end{tabular} Stimulates Insulin Secretion}

Thus, it has been known for over two decades that glucose stimulates diacylglycerol (DAG) synthesis de novo in islets of Langerhans [1], and it is well-established that this lipid second messenger directly activates the serine/threonine kinase PKC to stimulate insulin secretion [2]. DAG can also be hydrolysed by DAG lipases to form another lipid-derived messenger, arachidonic acid (AA), which can also stimulate insulin secretion $[3,4]$. It has been suggested that DAG hydrolysis to AA is essential for insulin release in response to glucose since RHC80267, a DAG lipase inhibitor, inhibits glucose-stimulated insulin secretion [5]. However, exogenous AA does not counteract the RHC-80267 inhibitory effects on glucose-induced insulin release [6], suggesting the existence of an alternative stimulatory mechanism downstream of DAG lipase.

DAG is metabolised to AA in a two stage process: $s n-1$ DAG lipases initially hydrolyse 1-stearoyl-2-arachidonyl-sn-glycerol to produce 2-arachidonoylglycerol (2-AG), then the $s n$ 2 bond of 2-AG is hydrolysed by a monoacylglycerol lipase (MGL) to release free AA. It is therefore possible that RHC-80267 [5] and tetrahydrolipstatin [7], another lipase inhibitor, inhibit insulin secretion by reducing production of 2-AG, rather than AA. Until relatively recently 2-AG was considered only as a precursor of AA without having any physiological function of its own, but it is now accepted that 2-AG acts as an endogenous agonist at cannabinoid receptors in a variety of cell types $[8,9]$, and its hydrolysis by MGL curtails its activity. DAG lipase and MGL activities have been identified in rat islet homogenates, where they induced rapid hydrolysis of radiolabelled DAG and 2-AG [5], supporting the notion that 2-AG may play a signalling role in islets.

In the past few years, we and others have reported expression of endocannabinoid system signalling elements by islet endocrine cells and the effects of cannabinoid receptor activation in regulating insulin secretion [10-18]. While most of these studies focused on the presence of cannabinoid receptors in the endocrine pancreas, there have been some reports on expression of endocannabinoids and the enzymes that regulate their generation and degradation. Thus, 2-AG production has been demonstrated in RINm5F cells [17], mouse pancreas $[17,18]$ and human islets [16]. It has also been reported that MGL immunoreactivity is present in both mouse and human pancreas, where it is mainly expressed by $\beta$-cells [16, 18], which is consistent with the earlier report of MGL activity in rat islets [5]. However, there is currently no information on the functional role of MGL in islets so we therefore investigated the expression and function of MGL in the mouse MIN6 $\beta$-cell line and in isolated human islets of Langerhans.

\section{Materials and Methods}

\section{Materials}

RPMI-1640, DMEM, CMRL-1066, penicillin/streptomycin, L-glutamine, Fura-2 AM, collagenase, histopaque and anti-glucagon antibody were purchased from Sigma-Aldrich (Dorset, UK). URB602 and 2AG were from Tocris Biosciences (Bristol, UK). Fetal bovine serum (FBS) was from Invitrogen (Paisley, UK). RNeasy mini kits and gel extraction kits were obtained from Qiagen (West Sussex, UK) and PCR primers were from Operon Biotech (Köln, Germany). The anti-MGL antibody was from Abcam plc (Cambridgeshire, UK), the anti-insulin antibody and Universal LSAB ${ }^{\mathrm{TM}}$ kits were from Dako UK Ltd (Cambridgeshire, UK). Standard PCR was carried out using a Px2 Thermal RT-PCR cycler (Thermo Scientific, Surrey, UK), and quantitative PCR was performed using a Lightcylcer 480 (Roche, West Sussex UK).

\section{Cell culture}

MIN6 cells [19] (passage 29-31) were maintained under standard tissue culture conditions at $37^{\circ} \mathrm{C}$ (95\% air/5\% $\mathrm{CO}_{2}$ ) in DMEM supplemented with $2 \mathrm{mM}$ glutamine, $10 \% \mathrm{FBS}, 100 \mathrm{U} / \mathrm{ml}$ penicillin and $100 \mu \mathrm{g} /$ $\mathrm{ml}$ streptomycin. Cells were seeded into uncharged $10 \mathrm{~cm}$ Petri dishes to form three dimensional clusters known as 'pseudoislets' [20] for insulin secretion experiments. 


\section{Cellular Physiology $\quad$ Cell Physiol Biochem 2012;30:347-358 \begin{tabular}{ll|l} 
and Biochemistry & $\begin{array}{l}\text { DOI: 10.1159/000339069 } \\
\text { Published online: June 26, 2012 }\end{array}$ & $\begin{array}{l}\text { ○ 2012 S. Karger AG, Basel } \\
\text { www.karger.com/cpb }\end{array}$ \\
$\begin{array}{l}\text { Li/Vilches-Flores/Zhao/Amiel/Jones/Persaud: Inhibition of Monoacylglycerol Lipase } \\
\text { Stimulates Insulin Secretion }\end{array}$
\end{tabular}}

Single-cell calcium microfluorimetry

MIN6 cells were seeded onto $2.2 \mathrm{~cm}$ circular acid/ethanol washed sterile glass cover-slips with an average density of 30,000 cells per cover-slip and maintained under standard cell culture conditions for 24 hours. They were then incubated with $5 \mu \mathrm{M}$ Fura- $2 \mathrm{AM}$ at $37^{\circ} \mathrm{C}$ for 30 minutes before being perifused with a physiological buffer [21] in the presence and absence of a pharmacological MGL inhibitor, URB602. Changes in intracellular $\mathrm{Ca}^{2+}$ were determined as previously described [22].

\section{Islet isolation}

Human islets were obtained from pancreases of non-diabetic, heart-beating organ donors with appropriate ethical permission, as detailed previously [23], and mouse islets were isolated from ICR mice by collagenase digestion of the exocrine pancreas followed by purification on histopaque gradients [24]. The isolated islets were maintained in culture for up to 48 hours at $37^{\circ} \mathrm{C}\left(95 \%\right.$ air $\left./ 5 \% \mathrm{CO}_{2}\right)$ before use. The human islets obtained from one donor showed unusually high expression of preproinsulin mRNA ( $>97 \%$; $<3 \%$ glucagon and somatostatin mRNAs), and these islets were used as a source of enriched human $\beta$-cells for mRNA analysis. The donor was a 50 year old female with no recorded history of hyperinsulinaemia or hypoglycaemia.

\section{Determination of $m R N A$ expression by RT-PCR}

Total RNAs were extracted from MIN6 cells, mouse islets and human islets (either normal hormone distribution or $\beta$-cell-enriched) and reverse-transcribed to cDNAs as previously described [22]. The cDNAs were amplified for 38 cycles using synthetic oligonucleotide primers specifically designed for mouse MGL and human MGL (mMGL sense: 5'- TCG GAA CAA GTC GGA GGT-3'; antisense: 5'-TCA GCA GCT GTA TGC CAA AG-3'; 89 bp product; hMGL sense: 5'-CGT GCT CTC TCG GAA TAA GAC-3'; antisense: 5'-AGT TGG ATG CCG AAG CAC-3'; 93bp product). The PCR products were separated and visualised on $2 \%$ agarose gels. Quantitative PCR was performed using mouse islet cDNAs and primers specific for mouse MGL and FAAH (qmMGL sense: 5'-CAG AGA GGC CAA CCT ACT TT-3'; antisense: 5'-ATG CGC CCC AAG GTC ATA TTT-3'; 138 bp product, 30 cycles; qmFAAH sense: 5'-GCT GTG CTC TTT ACC TAC CTG-3'; antisense: 5'-GAA GCA TTC CTT GAG GCT CAC3'; 152 bp product, 15 cycles) and normalised to $18 \mathrm{~S}$ rRNA copy numbers. In all qPCR experiments negative controls in which PCR reactions were performed without cDNA templates were included and specificity of primers was confirmed by melting curve analysis at the end of each PCR reaction.

\section{Immunohistochemistry}

Human pancreas was fixed in $4 \%$ paraformaldehyde and embedded in wax. Consecutive $5 \mu \mathrm{m}$ sections were cut onto microscope slides then dewaxed and rehydrated in xylene and ethanol, respectively, followed by permeabilisation with $0.1 \%(\mathrm{v} / \mathrm{v}$ ) Triton X-100/0.25\% BSA in PBS. After serum blocking, the human pancreas sections were incubated overnight with mouse anti-insulin and glucagon antibodies $(1 / 100)$ or a rabbit MGL antibody (1/100). Immunoreactive proteins were detected using a horseradish peroxidaseconjugated secondary antibody and a peroxidase-based Universal LSAB ${ }^{\mathrm{TM}}$ kit according to the manufacturer's instructions. The signals were amplified using the chromogenic peroxidase substrate diaminobenzidine (DAB) and visualised under a light microscope.

\section{Dynamic measurements of insulin secretion}

MIN6 cell pseudoislets [20] and isolated human islets were perifused in physiological buffer supplemented with selected reagents at a flow rate of $0.5 \mathrm{ml} / \mathrm{min}$ at $37^{\circ} \mathrm{C}$ in a temperature-controlled environment $[11,12]$. Perifusate fractions were collected every 2 minutes for the duration of the experiments, and insulin and glucagon contents were determined by radioimmunoassay [25].

\section{Statistical analyses}

All numerical data are expressed as means \pm SEM of multiple measurements. Student's $t$-tests were used for statistical comparisons and values of $\mathrm{P}<0.05$ were considered statistically significant. 


\section{Cellular Physiology $\quad$ Cell Physiol Biochem 2012;30:347-358 \\ \begin{tabular}{ll|l} 
and Biochemistry & $\begin{array}{l}\text { DOI: 10.1159/000339069 } \\
\text { Published online: June 26, 2012 }\end{array}$ & $\begin{array}{l}\text { ( ) 2012 S. Karger AG, Basel } \\
\text { www.karger.com/cpb }\end{array}$ \\
\cline { 2 - 3 }
\end{tabular} \\ Li/Vilches-Flores/Zhao/Amiel/Jones/Persaud: Inhibition of Monoacylglycerol Lipase Stimulates Insulin Secretion}

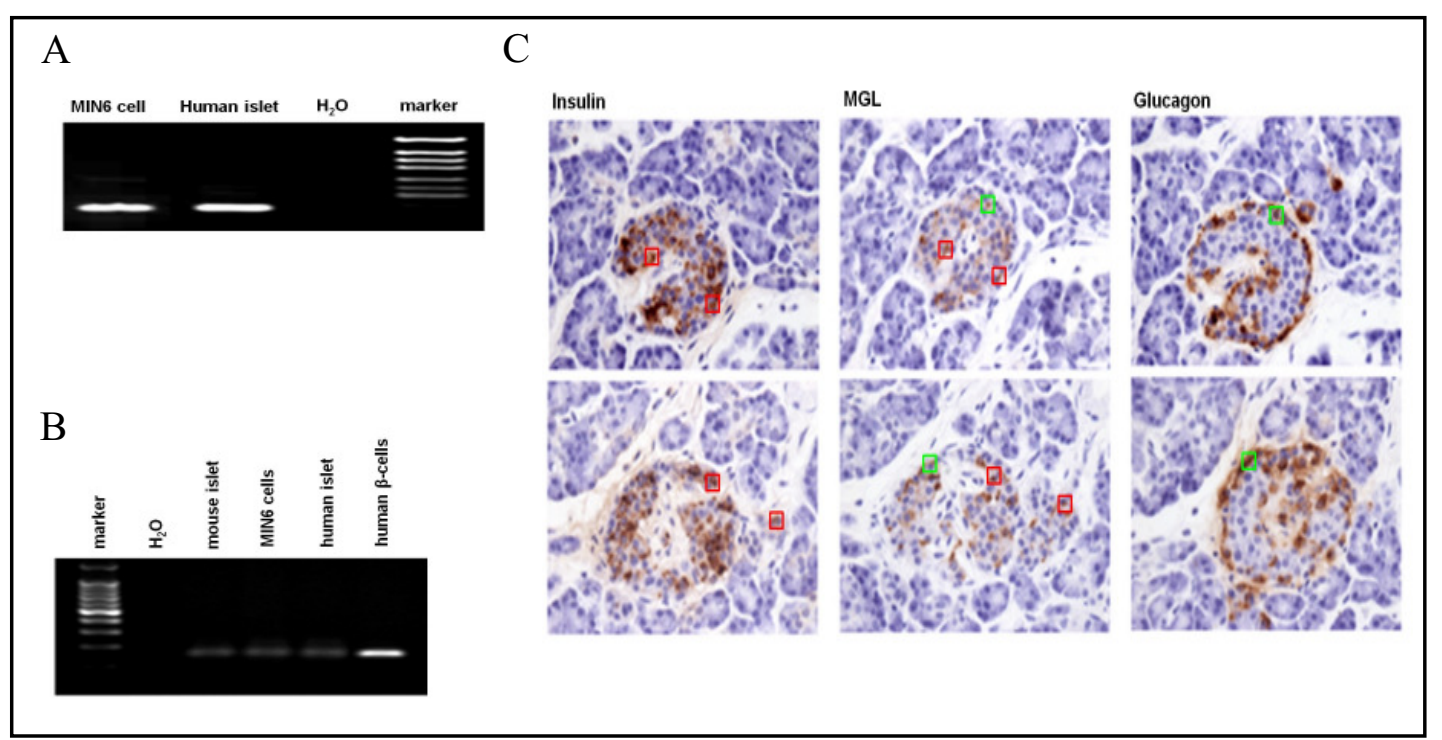

Fig. 1. Expression of MGL by mouse and human islet cells. (A) and (B): Amplicons of the correct sizes coding for mouse MGL (89bp) and human MGL (93bp) were amplified from cDNAs extracted from MIN6 $\beta$-cells (A and B), mouse islets (B), human islets (A and B) and enriched human islet $\beta$-cells (B). No products were amplified when molecular biological grade water was used in place of cDNA. (C): Three consecutive sections of two human pancreas samples were immunoprobed with antibodies directed against insulin (left) MGL (middle) and glucagon (right), and positive immunoreactivity was detected with a DAB-reactive horseradish peroxidase-conjugated secondary antibody (brown). The DAB-labelled sections were counterstained with haematoxylin (purple). MGL staining was observed in some $\beta$ - and $\alpha$-cells, examples of which are shown by the red and green boxes, respectively.

\section{Results}

Expression of the endocannabinoid degrading enzyme MGL was first determined by RTPCR using cDNAs obtained from mouse MIN6 $\beta$-cells and human islets, and single products of $89 \mathrm{bp}$ and $93 \mathrm{bp}$ for mouse and human MGL respectively were detected as shown in Figure 1A. Since human islets normally comprise approximately $60 \% \beta$-cells and $35 \% \alpha$-cells [26], RTPCR using mRNAs from whole islets cannot provide information about whether transcripts of interest are expressed by $\beta$-cells. We therefore carried out additional RT-PCR analyses using a $\beta$-cells -enriched human islet preparation, which contained over $97 \%$ insulin-expressingcells and 1-2\% glucagon- and somatostatin-expressing cells. This indicated that an MGL amplicon was readily detectable in the enriched $\beta$-cell preparation, although absolute mRNA expression levels were not quantified because of the limited amount of material available (Fig. 1B). It can also be seen from Figure 1B that mouse islets express MGL mRNA, and quantitative RT-PCR indicated that it was present at very low levels in islets $(0.03 \pm 0.004 \%$ of the mRNA expression of the other main endocannabinoid degrading enzyme FAAH, $n=5$ ).

The mRNA expression analyses were complemented by immunohistochemistry to identify the cellular localisation of MGL protein in human islets. A non-amplification detection system (FITC-conjugated secondary antibody) was not sufficiently sensitive to detect the low levels of MGL in pancreas sections so subsequent immunohistochemistry studies used a labelled streptavidin biotin method in which an HRP-streptavidin conjugate binds to a biotinylated secondary antibody/primary antibody complex followed by chromogenic visualisation. These studies with the streptavidin-based amplification system used consecutive sections of human pancreas that were immunoprobed with primary antibodies directed against human MGL, insulin and glucagon. As illustrated in Figure 1C, MGL-expressing cells were scattered throughout the islets with no immunoreactivity visible 


\section{Cellular Physiology $\quad$ Cell Physiol Biochem 2012;30:347-358 \begin{tabular}{ll|l} 
and BiOchemistry & $\begin{array}{l}\text { DOI: 10.1159/000339069 } \\
\text { Published online: June 26, 2012 }\end{array}$ & $\begin{array}{l}\text { C 2012 S. Karger AG, Basel } \\
\text { www.karger.com/cpb }\end{array}$ \\
\cline { 2 - 3 } & Li/Vilches-Flores/Zhao/Amiel/Jones/Persaud: Inhibition of Monoacylglycerol Lipase
\end{tabular} Stimulates Insulin Secretion}

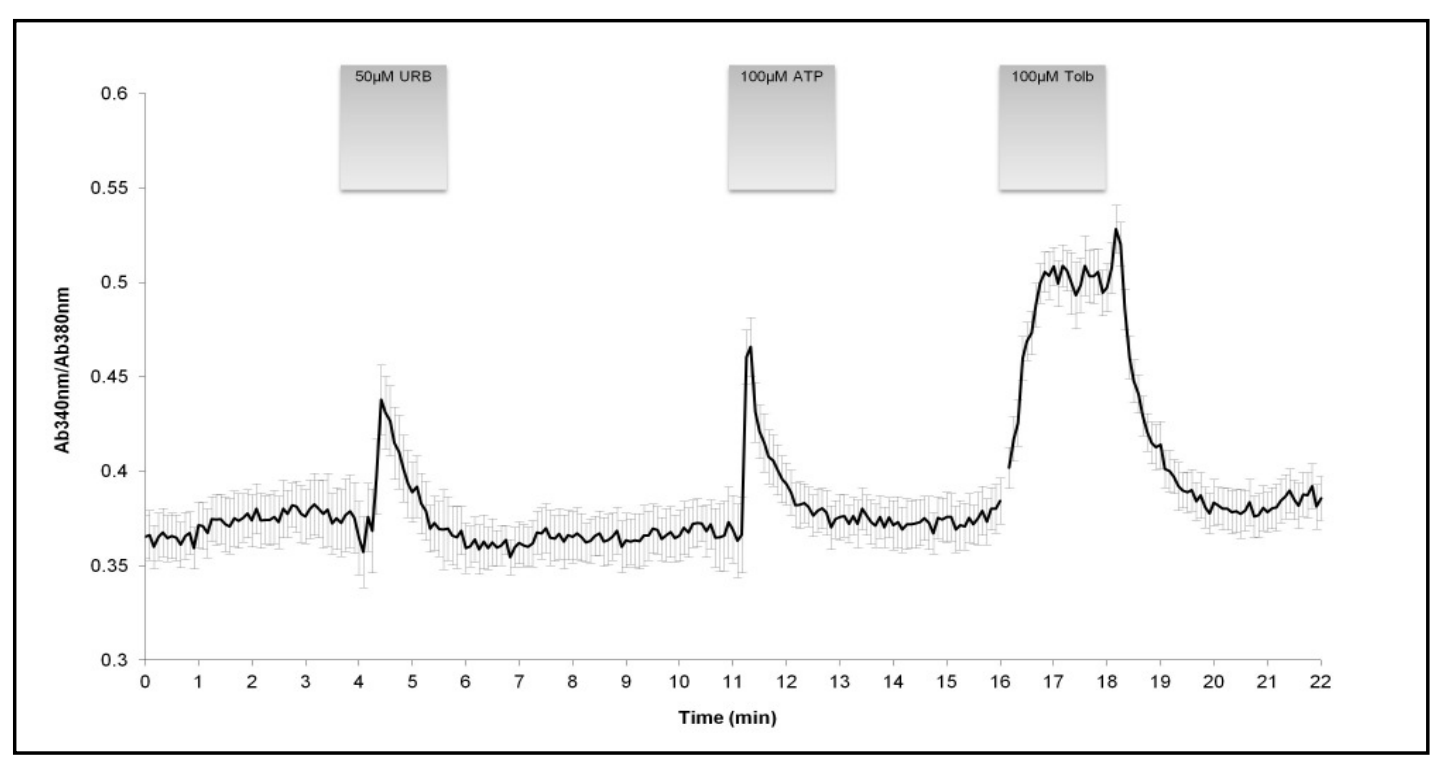

Fig. 2. Inhibition of MGL increases $\left[\mathrm{Ca}^{2+}\right]_{\mathrm{i}}$ in MIN6 $\beta$-cells. Fura-2-loaded MIN6 $\beta$-cells were exposed to the agents shown by the grey bars, in a physiological buffer supplemented with $2 \mathrm{mM}$ glucose. Changes in $\left[\mathrm{Ca}^{2+}\right]_{\mathrm{i}}$ in individual cells are expressed as $340 \mathrm{~nm} / 380 \mathrm{~nm}$ ratiometric data (means $\pm \mathrm{SEM}, \mathrm{n}=15$ cells, representative of data obtained with 53 cells).

in the exocrine pancreas. It is not possible to directly overlay the immunohistochemistry images of consecutive sections, but co-expression of insulin and MGL was observed in a small number of $\beta$-cells, some of which are highlighted in red on the micrographs, and some cells also appeared to co-express MGL and glucagon (shown in green squares).

We have previously reported that exogenous 2-AG increases intracellular $\mathrm{Ca}^{2+}$ levels $\left(\left[\mathrm{Ca}^{2+}\right]_{\mathrm{i}}\right)$ in mouse $\beta$-cells $[10,11]$ and since inhibition of MGL will elevate endogenous $2-\mathrm{AG}$ the effect of MGL inhibition on $\beta$-cell $\left[\mathrm{Ca}^{2+}\right]_{\mathrm{i}}$ was assessed in Fura-2 AM-loaded MIN6 $\beta$-cells. As shown in Figure 2, administration of $50 \mu \mathrm{M}$ URB602, a MGL inhibitor, elicited a rapid, reversible increase in MIN6 $\beta$-cell $\left[\mathrm{Ca}^{2+}\right]_{\mathrm{i}}(\mathrm{P}<0.01)$. These MIN6 cells remained functionally competent after exposure to URB602 because the expected elevations in $\left[\mathrm{Ca}^{2+}\right]_{\mathrm{i}}$ were observed when the cells were subsequently treated with the purinergic agonist ATP and the sulphonylurea tolbutamide (Fig. 2).

Further functional consequences of MGL inhibition in the presence of URB602 were determined by dynamic measurements of insulin secretion, as shown in Figure 3. For these perifusion experiments MIN6 $\beta$-cells were configured to form three-dimensional pseudoislets, which more closely resemble the physiological attributes of primary islets than do MIN6 cells grown as monolayers [20]. Addition of 50 $\mu$ M URB602 in the presence of a substimulatory glucose concentration $(2 \mathrm{mM})$ induced a rapid elevation of insulin release from MIN6 pseudoislets ( $324 \pm 56 \%$ peak stimulation over secretion at $2 \mathrm{mM}$ glucose, $\mathrm{p}<0.01, \mathrm{n}=4$ ). Insulin secretion rapidly returned to levels obtained in the presence of $2 \mathrm{mM}$ glucose alone, despite the continued presence of URB602 and this was followed by a decrease in insulin secretion to a nadir of $31 \pm 10 \%$ basal at $t=30$ minutes (Fig. 3A). Removal of URB602 and perifusion with buffer containing $2 \mathrm{mM}$ glucose led to a gradual recovery of insulin secretion, and the pseudoislets then responded to a challenge with $20 \mathrm{mM}$ glucose with a significant, sustained increase in insulin release $(p<0.05, n=4)$, demonstrating that URB602 had no deleterious effects on insulin secretory function. In parallel experiments administration of $50 \mu \mathrm{M}$ URB602 also potentiated glucose-induced insulin secretion from MIN6 pseudoislets (Fig. 3B). The stimulatory effect of URB 602 at $20 \mathrm{mM}$ glucose was transient and followed by a decline in insulin output to levels not significantly different from those obtained at $2 \mathrm{mM}$ glucose alone $(72 \pm 20 \%$ basal), despite the presence of $20 \mathrm{mM}$ glucose. This low level of insulin secretion continued for another 10 minutes after URB602 was removed. 


\section{Cellular Physiology $\quad$ Cell Physiol Biochem 2012;30:347-358 \begin{tabular}{ll|l} 
and Biochemistry & $\begin{array}{l}\text { DOI: 10.1159/000339069 } \\
\text { Published online: June 26, 2012 }\end{array}$ & $\begin{array}{l}\text { } 2012 \text { S. Karger AG, Basel } \\
\text { www.karger.com/cpb }\end{array}$ \\
\cline { 2 - 3 } & Li/Vilches-Flores/Zhao/Amiel/Jones/Persaud: Inhibition of Monoacylglycerol Lipase
\end{tabular} Stimulates Insulin Secretion}

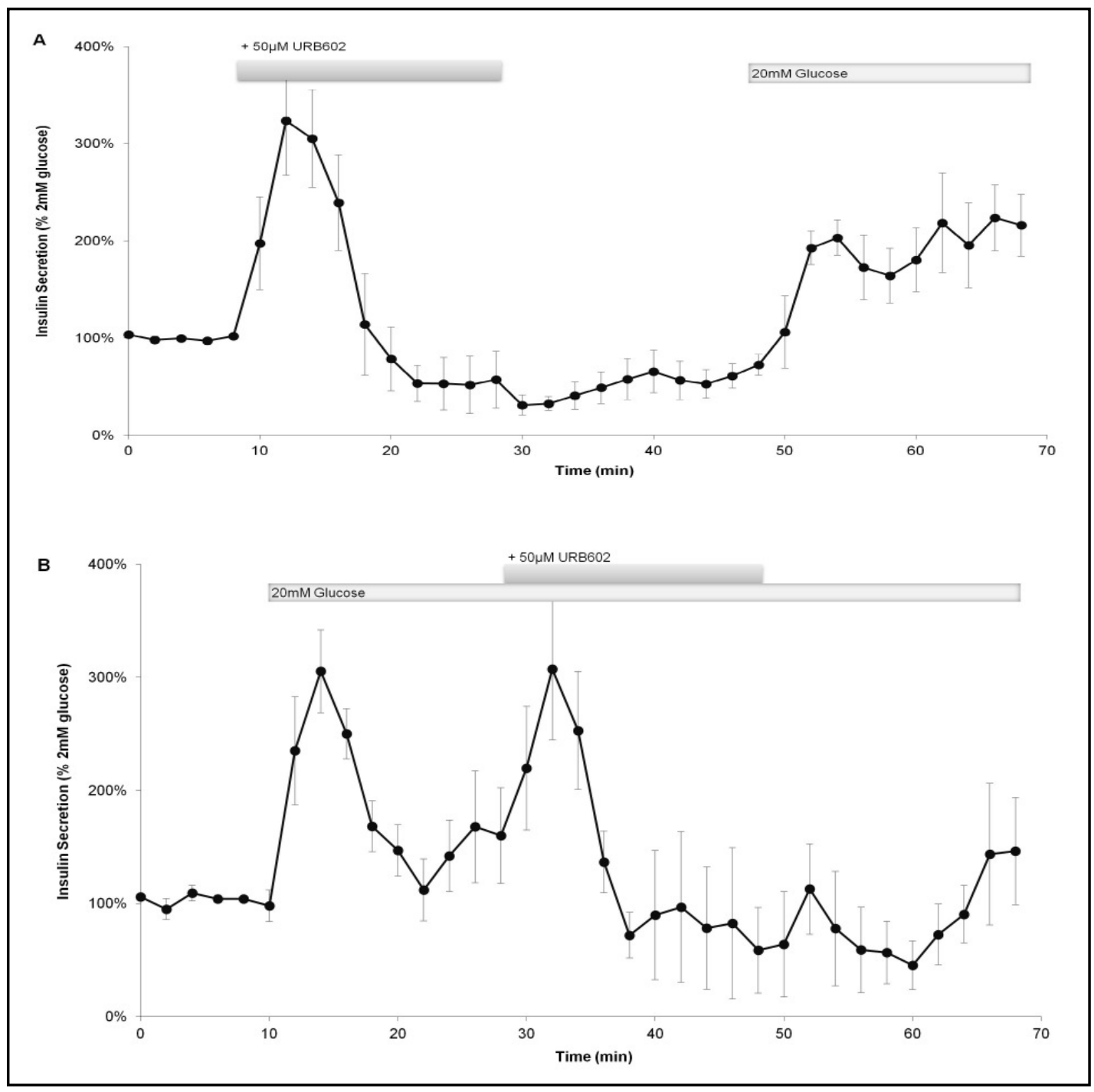

Fig. 3. Effect of MGL inhibition on insulin secretion from MIN6 pseudoislets. MIN6 $\beta$-cells configured as three-dimensional pseudoislets were perifused at $37^{\circ} \mathrm{C}$ with a physiological buffer supplemented with $50 \mu \mathrm{M}$ URB602 (grey bar) in the presence of $2 \mathrm{mM}$ glucose (A) and $20 \mathrm{mM}$ glucose (B). Data are presented percentages of insulin secretion at $2 \mathrm{mM}$ glucose (mean $\pm S E M, n=4)$.

Inhibition of MGL by URB602 would lead to elevated endogenous 2-AG levels, so MIN6 pseudoislet secretory profiles in the presence of exogenous 2-AG were also determined. Figure $4 \mathrm{~A}$ shows that $10 \mu \mathrm{M} 2-\mathrm{AG}$ caused a significant $(\mathrm{P}<0.05)$, but transient stimulation of insulin release in the presence of $2 \mathrm{mM}$ glucose, and there was a small rebound increase in secretion following 2-AG removal at $\mathrm{t}=30$ minutes. The MIN6 pseudoislets responded to a subsequent challenge with $20 \mathrm{mM}$ glucose, confirming their maintained secretory function. Addition of $10 \mu \mathrm{M} 2-\mathrm{AG}$ also enhanced glucose-induced insulin secretion from MIN6 pseudoislets (Fig. $4 B$ ), with a profile very similar to that obtained in the presence of URB602, as shown in Figure 3B. Thus, 2-AG initially caused a rapid elevation of insulin release above the $20 \mathrm{mM}$ glucose plateau response before the onset of a small inhibition that was reversible following the removal of 2-AG.

As the PCR and immunohistochemistry data indicated that human islet $\beta$-cells express MGL, perifusion experiments with URB602 were also performed using physiologically relevant isolated human islets, as shown in Figure 5. Figure 5A demonstrates that URB602 significantly $(\mathrm{P}<0.05)$ stimulated insulin secretion from human islets at a substimulatory 


\section{Cellular Physiology ～Cell Physiol Biochem 2012;30:347-358 \begin{tabular}{ll|l} 
and Biochemistry & $\begin{array}{l}\text { DOI: 10.1159/000339069 } \\
\text { Published online: June 26, 2012 }\end{array}$ & $\begin{array}{l}\text { } 2012 \text { S. Karger AG, Basel } \\
\text { www.karger.com/cpb }\end{array}$ \\
\cline { 2 - 3 } & Li/Vilches-Flores/Zhao/Amiel/Jones/Persaud: Inhibition of Monoacylglycerol Lipase
\end{tabular} Stimulates Insulin Secretion}

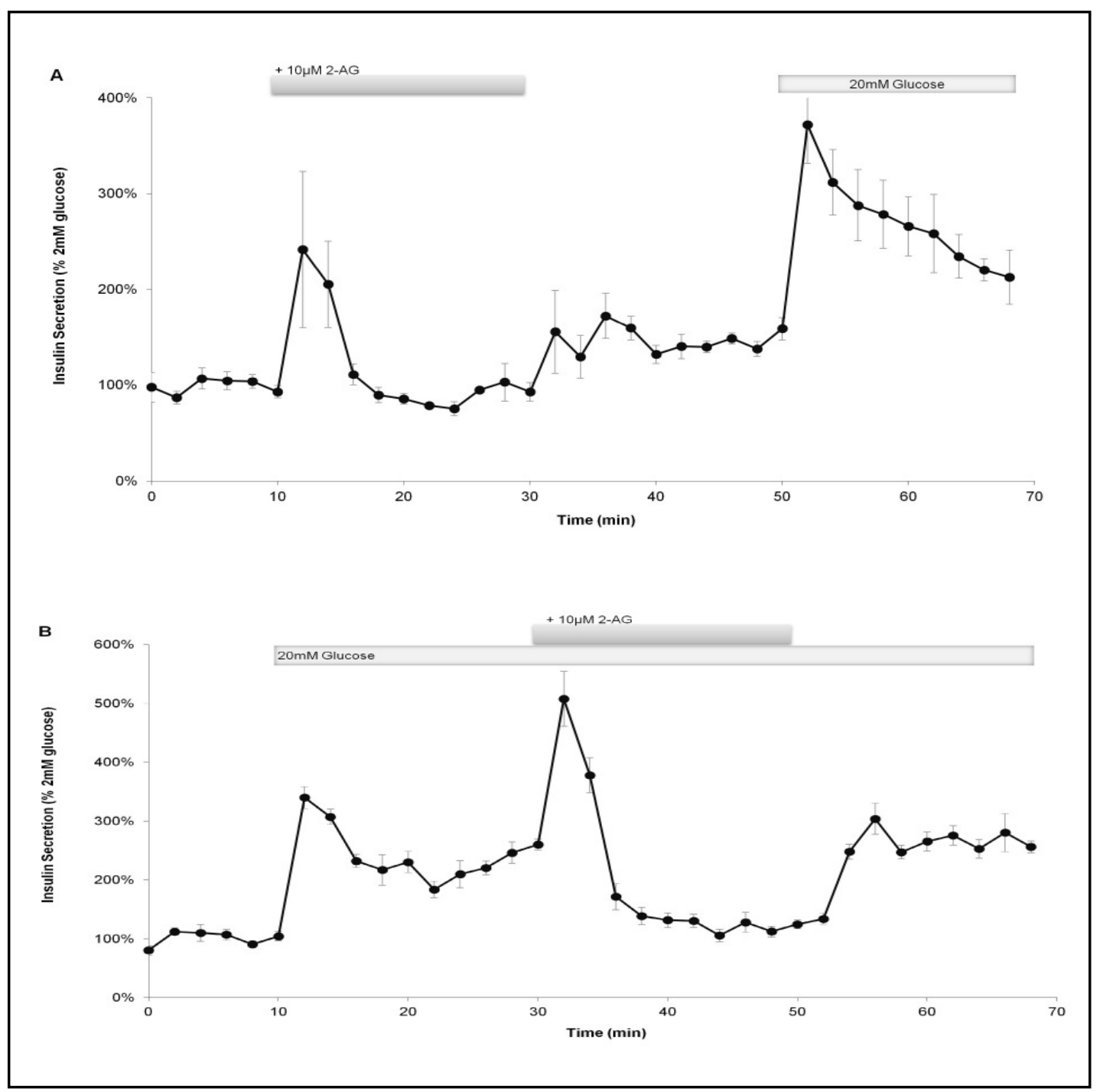

Fig. 4. Effect of exogenous 2-AG on insulin secretion from MIN6 pseudoislets. MIN6 $\beta$-cells configured as three-dimensional pseudoislets were perifused at $37^{\circ} \mathrm{C}$ with a physiological buffer supplemented with $10 \mu \mathrm{M}$ 2-AG (grey bar) in the presence of $2 \mathrm{mM}$ glucose $(\mathrm{A})$ and $20 \mathrm{mM}$ glucose $(\mathrm{B})$. Data are presented as percentages of insulin secretion at $2 \mathrm{mM}$ glucose (mean $\pm S E M, n=4)$.

glucose concentration $(2 \mathrm{mM})$ and, as had been observed with MIN6 pseudoislets, this response was not maintained for the duration of the URB602 stimulus. The islets responded to a subsequent exposure to $20 \mathrm{mM}$ glucose with a peak secretory response that was approximately 9-fold basal levels, and further exposure to URB602 in the presence of $20 \mathrm{mM}$ glucose induced a significant $(\mathrm{P}<0.01)$, transient increase in insulin output. URB602 also stimulated a substantial increase in glucagon secretion from perifused human islets at $2 \mathrm{mM}$ glucose $(\mathrm{P}<0.01)$, which lasted for the entire duration of the URB602 treatment (Fig. 5B). The elevation was rapidly reversed to pre-stimulatory levels after the inhibitor was removed.

\section{Discussion}

The importance of the ECS in modulating metabolism and energy expenditure has been the subject of several recent reviews [e.g. 9, 13, 27-28] and there have now been numerous reports of expression of $\mathrm{CB} 1$ and $\mathrm{CB} 2$ cannabinoid receptors in rodent and human islets 


\section{Cellular Physiology

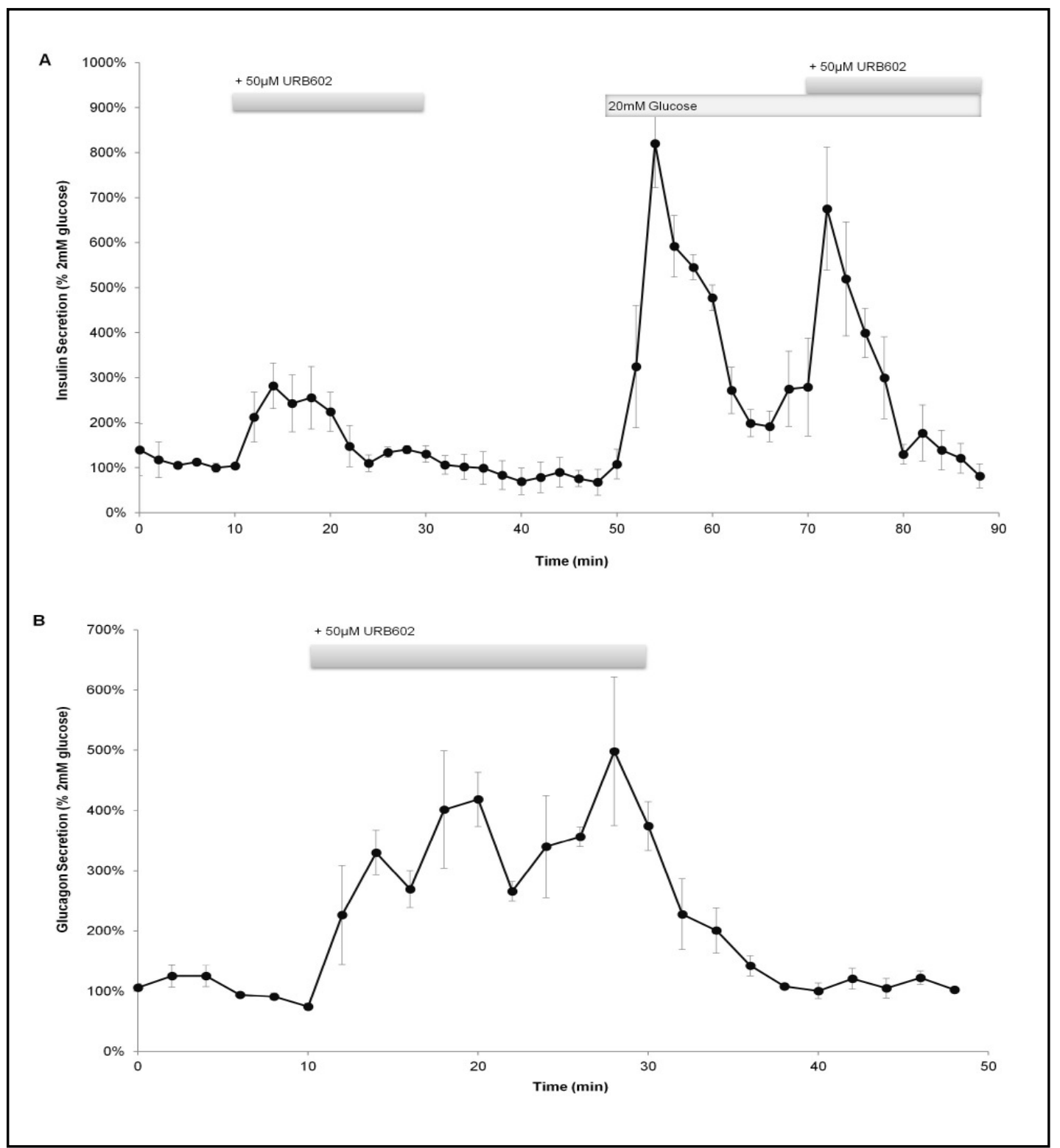

Fig. 5. Effect of MGL inhibition on insulin and glucagon secretion from human islets. (A) Human islets were perifused at $37^{\circ} \mathrm{C}$ with a physiological buffer containing $2 \mathrm{mM}$ glucose for the first 10 minutes and supplemented with $50 \mu \mathrm{M}$ URB602 for the next 20 minutes (grey bar). At $\mathrm{t}=30-50$ min the buffer contained $2 \mathrm{mM}$ glucose and for the final 40 minutes the glucose concentration was increased to $20 \mathrm{mM}$ and supplemented with URB602 as shown (grey bar). Data are presented as percentages of insulin secretion at $2 \mathrm{mM}$ glucose (mean $\pm \mathrm{SEM}, \mathrm{n}=3$ ). (B) Isolated human islets were perifused at $37^{\circ} \mathrm{C}$ with a physiological buffer supplemented with $50 \mu \mathrm{M}$ URB602 (grey bar) in the presence of $2 \mathrm{mM}$ glucose. Data are presented as percentages of glucagon secretion at $2 \mathrm{mM}$ glucose (mean $\pm \mathrm{SEM}, \mathrm{n}=3$ ).

[10-18]. Although there is some disagreement regarding the expression patterns of CB1 and $\mathrm{CB} 2$ receptors within islets and their effects on $\beta$-cell secretory responses, both cannabinoid receptors have been identified in mouse and human $\beta$-cells, and stimulatory effects of CB1 and CB2 receptor activation on insulin secretion have also been demonstrated $[10-12,16-$ 17]. However, while most studies focused on the cannabinoid receptors, only a few have investigated the localisation of other ECS components in islets $[16,18]$. The endocannabinoid, 2-AG, is synthesised and degraded on demand by DAG- and monoacylglycerol-lipases, so these enzymes also indirectly regulate the activity of cannabinoid receptors. 


\section{Cellular Physiology $\quad$ Cell Physiol Biochem 2012;30:347-358 \begin{tabular}{ll|l} 
and Biochemistry & $\begin{array}{l}\text { DOI: 10.1159/000339069 } \\
\text { Published online: June 26, 2012 }\end{array}$ & $\begin{array}{l}\text { ○ 2012 S. Karger AG, Basel } \\
\text { www.karger.com/cpb }\end{array}$ \\
\cline { 2 - 3 } Li/Vilches-Flores/Zhao/Amiel/Jones/Persaud: Inhibition of Monoacylglycerol Lipase
\end{tabular} Stimulates Insulin Secretion}

MGL is responsible for the removal of the endocannabinoid 2-AG, facilitating its hydrolysis to arachidonic acid (AA), a second messenger molecule that is generated in islets by phospholipase $\mathrm{A}_{2}$-mediated hydrolysis of membrane phospholipids [3]. MGL has previously been detected in both rodent and human pancreas, where it is reported to be mainly expressed by $\beta$-cells $[5,16,18]$, although one study has indicated expression by islet $\delta$-cells [29]. The results of the current study indicate that MGL mRNA is present in mouse $\beta$-cells and in $\beta$-cell-enriched human islets and the pattern of MGL expression in human pancreas is consistent with localisation to some, but not all, $\beta$-cells, and also to some $\alpha$-cells. The low level of MGL mRNA expression in mouse islets, as indicated by quantitative RT-PCR and the necessity of HRP-DAB staining for visualisation of MGL protein in human islets, is consistent with earlier reports of low MGL expression in mouse [18] and human [16] islets.

A selective MGL inhibitor, URB602, was employed to investigate the role played by MGL in $\beta$-cell function. This cyclohexyl ester is reported to inhibit brain MGL with an IC ${ }_{50}$ of $28 \mu \mathrm{M}$ and it does not exert inhibitory effects on other lipid metabolising enzymes at concentrations up to $100 \mu \mathrm{M}$ [30]. In our experiments $50 \mu \mathrm{M}$ URB602 elicited a rapid, reversible increase in $\left[\mathrm{Ca}^{2+}\right]_{\mathrm{i}}$ in MIN6 $\beta$-cells, which was most likely a consequence of elevations in endogenous 2-AG since this lipid is synthesised in islets [16] and RINm5F insulinoma cells [17] and we have previously demonstrated the stimulatory effect of exogenous $2-\mathrm{AG}$ on $\left[\mathrm{Ca}^{2+}\right]_{\mathrm{i}}$ in mouse islet cells [10].

It is well-established that elevations in intracellular $\mathrm{Ca}^{2+}$ levels trigger exocytosis, but insulin secretion is also regulated by a large number of mediators, including the paracrine influences of neighbouring $\alpha$ - and $\delta$-cells. Thus, glucagon, produced by $\alpha$-cells, potentiates insulin secretion, whereas somatostatin from islet $\delta$-cells, inhibits insulin release. To minimise such cross-regulatory influences and focus on the direct effects of MGL inhibition on $\beta$-cell function, MIN6 $\beta$-cells were configured into pseudoislet clusters [20] and a perifusion system was employed to investigate dynamic insulin secretory profiles. These perifusion experiments demonstrated that inhibition of MGL activity with URB602 transiently increased basal insulin output from MIN6 cells, and a similar transient potentiation of insulin release in response to $20 \mathrm{mM}$ glucose was also observed in the presence of URB602. The secretory profiles of URB602-treated MIN6 $\beta$-cells were similar to those obtained following exposure of MIN6 cells to exogenous 2-AG, consistent with URB602 exerting its effects via increasing endogenous 2-AG levels. Human islets acutely exposed to URB602 also responded with a short-lived initiation of basal insulin release and potentiation of glucose-stimulated insulin secretion. These profiles were analogous to those we have previously reported for human islets in the presence of 2-AG [12], again consistent with enhanced insulin secretion resulting from accumulation of endogenous 2-AG.

The mechanism by which locally generated 2-AG influences islet hormone secretion is unclear. It has recently been reported that some CB1 receptors have an intracellular localisation on neuronal mitochondrial membranes, where they are coupled to decreased oxygen consumption [31]. This would permit endocannabinoids to exert effects in the cells in which they are generated, but is unlikely to explain the stimulation of insulin secretion in response to URB602 since inhibition of mitochondrial respiration would be expected to reduce insulin output. Accumulation of 2-AG in the central nervous system is thought to exert local effects by activating CB1 receptors on neighbouring cells [32] and the limited diffusion capacity of endocannabinoids in hippocampal slices, to within $\leq 20 \mu \mathrm{m}$ from their site of production [33], supports their site of action being at cells within close proximity. Thus, in islets 2-AG could act at cannabinoid receptors on the cell in which it was generated, as well as at adjacent $\beta$-cells, to stimulate insulin secretion. In addition, analysis of human islet architecture has revealed widespread heterologous contact between $\beta$ - and $\alpha$-cells and homologous contacts between $\alpha$-cells [34], so it is possible that 2-AG accumulation following MGL inhibition in $\beta$-cells and $\alpha$-cells could activate $\alpha$-cell cannabinoid receptors to regulate glucagon release. Consistent with this, enhanced glucagon secretion was also observed following perifusion of human islets with URB602, consistent with an earlier report of a stimulatory effect of exogenous 2-AG on glucagon release from human islets in static incubation experiments [16]. This increased glucagon output may have resulted from 


\section{Cellular Physiology $\quad$ Cell Physiol Biochem 2012;30:347-358 \begin{tabular}{ll|l} 
and Biochemistry & $\begin{array}{l}\text { DOI: 10.1159/000339069 } \\
\text { Published online: June 26, 2012 }\end{array}$ & $\begin{array}{l}\text { C 2012 S. Karger AG, Basel } \\
\text { www.karger.com/cpb }\end{array}$ \\
\cline { 2 - 3 } Li/Vilches-Flores/Zhao/Amiel/Jones/Persaud: Inhibition of Monoacylglycerol Lipase
\end{tabular} Stimulates Insulin Secretion}

endogenous 2-AG accumulation in MGL-expressing $\alpha$-cells, or from $\beta$-cell 2-AG exerting paracrine effects on neighbouring $\alpha$-cells, or both. The increased insulin secretion following URB602 administration is unlikely to have been via glucagon-induced paracrine signalling since the insulin secretory response was transient while glucagon release was sustained.

In summary, the results presented in this study have demonstrated expression of MGL, the enzyme responsible for 2-AG degradation, in mouse and human islets. Blockade of MGL activity with a selective pharmacological inhibitor had stimulatory effects on $\beta$-cell $\mathrm{Ca}^{2+}$ levels and insulin secretion, and it also caused increased glucagon secretion. Accumulated 2-AG could stimulate islet hormone secretion via activation of conventional CB1 or CB2 receptors $[12,16]$, or through the novel cannabinoid receptor GPR55, which is expressed by $\beta$-cells $[13,35]$, and coupled to stimulation of insulin release [35]. The endogenous generation of 2AG through DAG hydrolysis may thus play a physiological role in regulating insulin secretion, and the increased levels of pancreatic 2-AG seen in obesity $[17,18]$ and hyperglycaemia [16] may be a physiological response to ameliorate insulin resistance by increasing insulin secretion.

\section{Acknowledgements}

This work was supported by Diabetes UK (RD06/0003201 and RD07/0003510) and the Henry Lester Trust. The development of the MIN6 pseudoislet model was supported by the UK National Centre for the Replacement, Refinement and Reduction of Animals in Research (NC3Rs). We are grateful to the relatives of organ donors for the pancreases used in our research for human islet isolation. We acknowledge the contribution of Dr Stefan Amisten for quantification of human islet hormone mRNA expression. Dr Alonso Vilches-Flores is supported by the Novo Nordisk UK Research Foundation, National Council of Science and Technology (CONACYT, Mexico \#00166231) and PASPA from the DGAPA-UNAM, Mexico.

\section{References}

1 Peter-Riesch B, Fathi M, Schlegel W, Wollheim CB: Glucose and carbachol generate 1.2-diacylglycerols by different mechanisms in pancreatic islets. J Clin Invest 1988;81:1154-1161.

2 Jones PM, Persaud SJ: Protein kinases, protein phosphrylation, and the regulation of insulin secretion from pancreatic beta-cells. Endocr Rev 1998;19:429-461.

3 Jones PM, Persaud SJ: Arachidonic acid as a second messenger in glucose-induced insulin secretion from pancreatic beta-cells. J Endocrinol 1993;137:7-14.

4 Persaud SJ, Muller D, Belin VD, Kitsou-Mylona I, Asare-Anane H, Papadimitriou A, Burns CJ, Peter-Riesch B, Fathi M, Schlegel W, Wollheim CB: Glucose and carbachol generate 1.2-Huang GC, Amiel SA, Jones PM: The role of arachidonic acid and its metabolites in insulin secretion from human islets of Langerhans. Diabetes 2007;56:197-203.

5 Konrad RJ, Major CD, Wolf BA: Diacylglycerol hydrolysis to arachidonic acid is necessary for insulin secretion from isolated pancreatic islets: sequential actions of diacylglycerol and monoacylglycerol lipases. Biochemistry 1994;33:13284-1394.

6 Thams P, Capito K: Inhibition of glucose-induced insulin secretion by the diacylglycerol lipase inhibitor RHC80267 and the phospholipase $\mathrm{A}_{2}$ inhibitor ACA through stimulation of $\mathrm{K}^{+}$permeability without diminution by exogenous arachidonic acid. Biochem Pharmacol 1997;53:1077-1086.

7 Mulder H, Yang S, Winzell MS, Holm C, Ahren B: Inhibition of lipase activity and lipolysis in rat islets reduces insulin secretion. Diabetes 2004;53:122-128.

8 Di Marzo V, De Petrocellis L, Bisogno T: The biosynthesis, fate and pharmacological properties of endocannabinoids. Handb Exp Pharmacol 2005;168:147-185.

9 Quarta C, Mazza R, Obici S, Pasquali R, Pagotto U: Energy balance regulation by endocannabinoids at central and peripheral levels. Trends Mol Med 2011;17:518-526. 


\section{Cellular Physiolosy $\quad$ Cell Physiol Biochem 2012;30:347-358 \begin{tabular}{ll|l} 
and Biochemistry & $\begin{array}{l}\text { DOI: 10.1159/000339069 } \\
\text { Published online: June 26, 2012 }\end{array}$ & $\begin{array}{l}\text { ○ 2012 S. Karger AG, Basel } \\
\text { www.karger.com/cpb }\end{array}$ \\
\cline { 2 - 3 } Li/Vilches-Flores/Zhao/Amiel/Jones/Persaud: Inhibition of Monoacylglycerol Lipase \\
Stimulates Insulin Secretion
\end{tabular}}

10 Li C, Bowe JE, Jones PM, Persaud SJ : Expression and function of cannabinoid receptors in mouse islets. Islets 2010;2:1-10.

11 Li C, Jones PM, Persaud SJ: Cannabinoid receptors are coupled to stimulation of insulin secretion from mouse MIN6 $\beta$-cells. Cell Physiol Biochem 2010;26:187-197.

12 Li C, Bowe JE, Huang GC, Amiel SA, Jones PM, Persaud SJ: Cannabinoid receptor agonists and antagonists stimulate insulin secretion from isolated human islets of Langerhans. Diabetes Obes Metab 2011;13:903910.

13 Li C, Jones PM, Persaud SJ: Role of the endocannabinoid system in food intake, energy homeostasis and regulation of the endocrine pancreas. Pharmacol Ther 2011;129, 307-20.

14 Juan-Pico P, Fuentes E, Bermudez-Silva FJ, Diaz-Molina FJ, Ripoll C, De Fonseca FR, Nadal A: Cannabinoid receptors regulate $\mathrm{Ca}^{2+}$ signals and insulin secretion in pancreatic beta-cells. Cell Calcium 2006;39:155162.

15 Nakata M, Yada T: Cannabinoids inhibit insulin secretion and cytosolic $\mathrm{Ca}^{2+}$ oscillation in islet beta-cells via CB1 receptors. Regul Pept 2008;145:49-53.

16 Bermudez-Silva FJ, Suarez J, Baixeras E, Cobo N, Bautista D, Cuesta-Munoz AL, Fuentes E, Huan-Pico P, Castro MJ, Milman G, Mechoulam R, Nadal A, De Fonseca FR: Presence of functional cannabinoid receptors in human endocrine pancreas. Diabetologia 2008;51:476-487.

17 Matias I, Gonthier MP, Orlando P, Martiadis V, De Petrocellis L, Cervino C, Petrosino S, Hoareau L, Festy F, Pasquali R, Roche R, Maj M, Pagotto U, Monteleone P, Di Marzo V: Regulation, function, and dysregulation of endocannabinoids in models of adipose and beta-pancreatic cells and in obesity and hyperglycemia. J Clin Endocrinol Metab 2006;91:3171-180.

18 Starowicz KM, Cristino L, Matias I, Capasso R, Racioppi A, Izzo AA, Di Marzo V: Endocannabinoid dysregulation in the pancreas and adipose tissue of mice fed with a high fat diet. Obesity 2008;16:553-565.

19 Ishihara H, Asano T, Tsukuda K, Katagiri H, Inukai K, Anai M, Kikuchi M, Yazaki Y, Miyazaki JI, Oka Y: Pancreatic beta cell line MIN6 exhibits characteristics of glucose metabolism and glucose-stimulated insulin secretion similar to those of normal islets. Diabetologia 1993;36:1139-1145.

20 Hauge-Evans A, Squires PE, Persaud SJ, Jones PM: Pancreatic beta-cell-beta-cell interactions are required for integrated responses to nutrient stimuli: enchanced $\mathrm{Ca}^{2+}$ and insulin secretory responses of MIN6 pseudoislets. Diabetes 1999;48:1402-1408.

21 Gey GO, Gey MK: Maintenance of human normal cells in continuous culture: cultivation of mesoblastic tumors and normal cells and notes on methods of cultivation. Am J Cancer 1936;27:45-76.

22 Persaud SJ, Roderigo-Milne HM, Squires PE, Sugden D, Wheeler-Jones CPD, Marsh PJ, Belin VD, Luther MJ, Jones PM: A key role for beta-cell cytosolic phospholipase $\mathrm{A}_{2}$ in the maintenance of insulin stores, but not in the initiation of insulin secretion. Diabetes 2002;51:98-104.

23 Huang GC, Zhao M, Jones P, Persaud S, Ramracheya R, Lobner K, Christie MR, Banga JP, Peakman M, Sirinivsan P, Rela M, Heaton N, Amiel S: The development of new density gradient media for the purification of human islets and islet quality assessments. Transplantation 2004;77:143-145.

24 Papadimitriou A, King AJ, Jones PM, Persaud SJ: Anti-apoptotic effects of arachidonic acid and prostaglandin E2 in pancreatic beta-cells. Cell Physiol Biochem 2007;20:607-616.

25 Jones PM, Salmon DM, Howell SL: Protein phosphorylation in electrically permeabilised islets of Langerhans. Effects of $\mathrm{Ca}^{2+}$, cyclic AMP, a phorbol ester and noradrenaline. Biochem J 1988;254:397-403.

26 Cabrera O, Berman DM, Kenyon NS, Ricordi C, Berggren PO, Caicedo A: The unique cytoarchitecture of human pancreatic islets has implications for islet cell function. Proc Natl Acad Sci USA 2006;103:23342339.

27 Cota D: CB1 receptors: emerging evidence for central and peripheral mechanisms that regulate energy balance, metabolism, and cardiovascular health. Diabet Metab Res Rev 2007;23:507-517.

28 De Kloet AD, Woods SC: Minireview: Endocannabinoids and their receptors as targets for obesity therapy. Endocrinol 2009;150:2531-2536.

29 Tharp WG, Lee YH, Maple RL, Pratley RE: The cannabinoid CB1 receptor is expressed in pancreatic deltacells. Biochem Biophys Res Commun 2008;372:595-600.

30 Hohmann AG, Suplita RL, Bolton NM, Neely MH, Fegley D, Mangieri R, Krey JF, Walker JM, Holmes PV, Crystal JD, Duranti A, Tontini A, Mor M, Tarzia G, Piomelli D: An endocannabinoid mechanism for stress-induced analgesia. Nature 2005;435:1108-1112. 


\section{Cellular Physiology Cell Physiol Biochem 2012;30:347-358 \begin{tabular}{ll|l} 
and Biochemistry & $\begin{array}{l}\text { DOI: 10.1159/000339069 } \\
\text { Published online: June 26, 2012 }\end{array}$ & $\begin{array}{l}\text { C 2012 S. Karger AG, Basel } \\
\text { www.karger.com/cpb }\end{array}$ \\
$\begin{array}{l}\text { Li/Vilches-Flores/Zhao/Amiel/Jones/Persaud: Inhibition of Monoacylglycerol Lipase } \\
\text { Stimulates Insulin Secretion }\end{array}$
\end{tabular}}

31 Benard G, Massa F, Puente N, Lourenco J, Bellocchio L, Soria-Gomez E, Matias I, Delamarre A, Metna-Laurent M, Cannich A, Hebert-Chatelain E, Mulle C, Ortega-Gutierrez S, Martin-Fontecha M, Klugmann M, Guggenhuber S, Lutz B, Gertsch J, Chaouloff F, Lopez-Rodriguez ML, Grandes P, Rossignol R, Marsicano G: Mitochondrial $\mathrm{CB}(1)$ receptors regulate neuronal energy metabolism. Nat Neurosci 2012;doi: 10. 1038/nn.3053.

32 Piomelli D, Giuffrida A, Calignano A, Rodriguez de Fonseca F: The endocannabinoid system as a target for therapeutic drugs. Trends Pharmacol Sci 2000;21:218-224.

33 Wilson RI, Nicoll RA: Endogenous cannabinoids mediate retrograde signalling at hippocampal synapses. Nature 2001;410:588-592.

34 Bosco D, Armanet M, Morel P, Niclauss N, Sgroi A, Muller YD, Giovannoni L, Parnaud G, Berney T: Unique arrangement of alpha- and beta-cells in human islets of Langerhans. Diabetes 2010;59:1202-1210.

35 Romero-Zerbo SY, Rafacho A, Diaz-Arteaga A, Suarez J, Quesada I, Imbernon M, Ross RA, Dieguez C, Rodriguez de Fonseca F, Nogueiras R, Nadal A, Bermudez-Silva FJ: A role for the putative cannabinoid receptor GPR55 in the islets of Langerhans. J Endocrinol 2011;211:177-185. 